\title{
Karen Whiteson
}

\section{frankenstein's daughter}

my maker's tyranny over me was the sad weight of him lying like a blanket

heavily

imbued with his own smell immobile, he laboured over my stubborn material he drew

a blueprint from my body, sketched in organs that flourished like blots from ink; my lungs revolted

at the rotting stuff his breath produced; $i$ could not make him see the monstrosity

i was

already a disguised thing when from his laboratory table $i$ rose a metaphorical creature, a rough

diamond gloved in fantastic skin displaying stitching along the stitching of my harlequin bones a patched-together

doll, re-animated by the hum of a rusty tune; $i$ visited myself upon my own flesh and blood looting

the junk-shop of ancestral corridors steeped in portraits and the raw stench of something red and old

$$
i \text { fed }
$$

at the table of the tallest stories

entirely consumed the chart of the digestive system the insoluble sum of the brain swims inside my head

grows bulbous with contradictory arrows as the equation is stretched to cover the human form

\section{Note}

Karen Whiteson is 30, lives in London and has been variously employed. She left her job a year ago in order to learn how to write. 